\title{
Standardization Process of Systems Technologies: creating a Balance between Competition and Cooperation
}

Citation for published version (APA):

van Wegberg, M. J. (1994). Standardization Process of Systems Technologies: creating a Balance between Competition and Cooperation. Technology Analysis \& Strategic Management, 6(4), 457-478. https://doi.org/10.1080/09537329408524186

Document status and date:

Published: 01/01/1994

DOI:

10.1080/09537329408524186

Document Version:

Publisher's PDF, also known as Version of record

Please check the document version of this publication:

- A submitted manuscript is the version of the article upon submission and before peer-review. There can be important differences between the submitted version and the official published version of record.

People interested in the research are advised to contact the author for the final version of the publication, or visit the DOI to the publisher's website.

- The final author version and the galley proof are versions of the publication after peer review.

- The final published version features the final layout of the paper including the volume, issue and page numbers.

Link to publication

\footnotetext{
General rights rights.

- You may freely distribute the URL identifying the publication in the public portal. please follow below link for the End User Agreement:

www.umlib.nl/taverne-license

Take down policy

If you believe that this document breaches copyright please contact us at:

repository@maastrichtuniversity.nl

providing details and we will investigate your claim.
}

Copyright and moral rights for the publications made accessible in the public portal are retained by the authors and/or other copyright owners and it is a condition of accessing publications that users recognise and abide by the legal requirements associated with these

- Users may download and print one copy of any publication from the public portal for the purpose of private study or research.

- You may not further distribute the material or use it for any profit-making activity or commercial gain

If the publication is distributed under the terms of Article $25 \mathrm{fa}$ of the Dutch Copyright Act, indicated by the "Taverne" license above, 


\title{
Standardization Process of Systems Technologies: Creating a Balance between Competition and Cooperation
}

\author{
MARC VAN WEGBERG \\ University of Maastricht, The Netherlands
}

\begin{abstract}
Many firms are experimenting with how to standardize new technologies. They may use proprietary technologies for their products and services, and let them compete in the market selection. Alternatively, they can cooperate to jointly set a standard and experiment with combinations of market process and cooperation. If firms let the market decide, they can compete with technologies and need not invest time and effort in hammering out a standard. If they do incur the costs of negotiated standardization, they may enable end users to realize the benefits of standards. A hybrid standardization process combines the advantages of both market selection and negotiated decision making. This paper presents a contingency framework to identify conditions that will affect the preferred standardization process for vendors who introduce new technologies. A major contingency that this paper points to is the systemic nature of technologies in information and communication technology industries. The more systemic the technology is (in a way to be clarified), the less likely that firms will establish a hybrid standardization process. One advantage of decomposing technology systems in smaller components (modules) is that this approach enables firms to combine market selection with negotiated selection of standards.
\end{abstract}

\section{Introduction}

Standards and how to establish them are important aspects of business strategy in the Information and Communication technology (ICT) industries. Firms have become very sophisticated about their standardization strategies. The Chief Technology Officer of a company like SUN has a responsibility for standards. As a part of their technology and product development strategy, firms dispatch staff to standard development organizations. Compatibility standards are important to firms because they enable the integration of components into systems. Technologies deployed in the ICT industries tend to be systems that combine different components such as hardware, software and network infrastructure. Combining disparate components into workable coherent systems is necessary to provide information and communication services. This makes the process of setting standards an important aspect of the value creating processes of innovating firms. How to select a standard is a matter of strategic importance. The

Correspondence Address: Marc van Wegberg, Faculty of Economics and Business Administration, University of Maastricht, P.O. Box 616, 6200 MD Maastricht, The Netherlands. Tel. + 31 43-3883654; Fax: + 31 43-3884893, E-mail: mvanwegberg@yahoo.com; Home page: http://www.geocities.com/ mvanwegberg/ 
standardization mode is the organizational process through which standards come about. Sophisticated firms perceive a broad range of possible standardization modes. They are learning how to combine competition and cooperation in setting standards for ICT technologies.

By an industry standard we mean 'a set of specifications to which all elements of products, processes, formats, or procedures under its jurisdiction must conform'. ${ }^{1}$ We focus in this paper on a particular kind of standard, namely compatibility standards. These specifications make it possible to connect different components (products or technologies) to establish a system. Systems combine several different components to provide services to end-users. There are positive network externalities, if the utility of a product (technology) to the user increases if the number of users of compatible technologies increases. The larger the number of these users, the more complementary product companies will develop for them (a so-called indirect network externality), or the more users can communicate with each other using compatible technologies (a direct network externality). ${ }^{2}$ If different technologies combine to create a networked externality, they are called compatible. One way to achieve compatibility between components is by adopting compatibility standards.

There are different modes of organizing a standardization process. Firms attempt to tailor the standardization process to their business strategy. They can choose from a menu of modes of organizing a standardization process. Which standardization mode best serves the interests of the companies involved depends on various aspects of the situation. What is needed is a contingency approach to identify the conditions that determine the appropriate standardization mode. We flesh out the consequences of one major contingency in particular. This contingency is that the systems technology for which the standard or standards are intended is sufficiently modular (a condition that we will explain below).

Within the menu of possible standardization modes, the extreme modes are a market selection process of standards and a centrally coordinated, industry-wide choice of standards. In the market selection mode of standards, the product market decides which incompatible technologies get adopted. Firms submit their technologies to market selection by introducing products that use these technologies. Competition in the market place becomes a battle about standards. Vendors sponsor their preferred technology by using their competition instruments in support of it. ${ }^{3}$ If a single technology achieves dominance in the market, it is called a de facto standard. An advantage of this standardization mode is timely market introduction. Companies introduce products as soon as the technology is ready for it. A disadvantage of this standardization mode is that the market may fail to establish a de facto standard (for reasons we discuss later). As long as the market does not settle on a single standard, there is a loss of network externalities associated with the industry-wide adoption of a standard.

In a negotiated standardization mode, firms select a common standard in a collective decision-making process. There may be a permanent standard setting body that develops, selects, or imposes a standard. Firms collaborate in this process either voluntarily (as in an industry consortium) or constrained by law (when a government body sets standards). If potential rivals coordinate decision making to set a standard, they will achieve the benefits associated with adopting 
a standard. These advantages tend to be summarized by the concept of positive network externalities. The negotiation process takes time, however, and this will delay the market introduction. Vendors may participate in a negotiation process in order to speed it up. ${ }^{4}$ They may have more urgency that researchers or government officials. Politicking by competitive vendors may, however, delay the negotiations.

In between these standardization modes are increasingly refined hybrid forms. Examples abound in the data communication industry ${ }^{5}$ as well as in the telecommunication industry. ${ }^{6}$ The new and hybrid standardization modes combine elements from the existing standardization modes with some new approaches. ${ }^{7}$ Hybrid standardization modes can take a multitude of forms. Standardization may occur in coalitions of firms and other participants that compete with each other for standard setting. ${ }^{8}$ Firms may cooperate in an industry-wide coalition, while already introducing products in the market using competing versions of a potential standard. ${ }^{9}$ Firms may sponsor competing technologies, while trying to develop a compromise standard that combines elements from the competing technologies. ${ }^{10}$ Competing groups of firms and other organizations may standardize in a formal and open way, by submitting their proposals to competing standardization bodies. ${ }^{11}$

By engaging in a hybrid standardization mode, firms seek to combine the advantages of the market selection and negotiated modes. The advantage of cooperating is that firms create a basis for achieving positive network externalities. By competing with each other at the same time, they achieve some of the benefits of the market selection mode. The latter include timely market introduction and the ability of adopters to choose between alternative technologies and standards. It may, however, be possible that a hybrid standardization mode combines instead the disadvantages of the market selection and negotiated standardization modes. The cooperation that firms engage in may delay the actual adoption of new technologies. The competition between firms may lead to competition between incompatible technologies, thus wasting potential network externalities. The possibility that a hybrid standardization mode combines the worst of both worlds means that it is not always the best solution. This is why a contingency approach is needed to analyse the choice of standardization mode.

The paper begins with a review of the literature. This lays the basis for our contingency framework. This paper subsequently uses a game theoretic model to develop the causal relationships in the explanatory framework. We will focus on the interplay between three major factors: the competitive interaction of the firms, the nature of technology concerned, and the benefits realized by having a standard. Examples from the ICT industries illustrate the framework.

\section{Determinants of the Choice of Standardization Mode}

There are many different aspects of a standardization process that can explain which standardization mode pertains in a given case. For one, the standard selection mode tends to depend on the industry. Standardization in the computer industry mainly evolved through the market place ${ }^{12}$ or through standards organizations such as the ISO (International Organization for Standardization). 
In telecommunications, official standards bodies have defined many standards. Especially important is the ITU (International Telecommunications Union), which is a formal treaty organization and run under the auspices of the United Nations. ${ }^{13}$ The Internet has pioneered many open standards. These were incubated in research communities of universities by volunteer organizations such as the IETF (Internet Engineering Task Force).

The 1990s witnessed a lot of experimentation with new standardization forms and institutions. Many new approaches are hybrid market competition/ negotiation standardization modes. One reason for the experimentation is the liberalization of telecommunication markets worldwide. Liberalization allowed entry to take place in hitherto closed markets. This has increased the freedom of telecom equipment manufacturers and operators to select their suppliers, partners and technologies.

The theoretical industrial organization literature has analysed in depth how firms should use their freedom to standardize. The seminal paper on the choice of standardization mode in a context with network externalities is that of Farrell and Saloner. ${ }^{14}$ This classic paper has a dynamic model, where two firms choose a standard between two technologies. These firms engage in many rounds of decision making. They experience a positive network externality if they adopt the same technology, but each favours its own technology to be the one. There are profit benefits in having a standard, with an additional benefit if one's own technology is selected as standard (for example, because of intellectual property rights on the technology). Both firms can either adopt a technology unilaterally, thus letting the market select technologies, or join an industry-wide standard setting committee where they can propose a technology as a standard. In a hybrid standardization mode, firms repeatedly go through rounds of decision making. Each round begins with both firms unilaterally deciding whether or not to adopt their technology for a new product. If neither adopts unilaterally, both enter into a committee meeting to try to select a standard. This game continues until either one of them or both unilaterally adopt a technology, or both agree on a standard in a committee meeting.

Farrell and Saloner ${ }^{15}$ conclude from their model that the committee unambiguously outperforms the market selection case. The committee ensures that firms agree on a standard and realize positive network externalities. Market selection may be quick, but it runs the risk of firms adopting competing technologies, in which case they lose the positive network externalities. The market may fail to settle on a de facto standard. A hybrid standard selection mechanism that combines a committee with market selection is always superior to both a pure committee system and a pure market system. It is a reasonably quick way of selecting a standard, with a relatively small chance of firms unilaterally adopting competing technologies.

The paper by Farrell and Saloner ${ }^{16}$ shows the pitfall of the negotiated standardization mode: a conflict about which technology to standardize on can prolong the decision-making process, which creates an economic loss. It also argues that uncoordinated competitive behaviour by firms can lead to competition between technologies and a loss of network externalities. Farrell and Saloner's ${ }^{17}$ results predict that firms always participate in an industry-wide 
standardization committee, but would sometimes undercut their negotiations, thereby unilaterally adopting their own technology in an investment. This is surely an interesting result now that we so often observe hybrid systems. It cannot explain, however, why an industry-wide committee sometimes fails to be formed, or why firms participate in a committee with such a commitment that going alone would no longer be possible. To understand this, we need an approach that allows firms to make different strategic choices, depending on the situation. By including other factors in the explanation, besides network externalities, we develop a contingency approach where contingencies determine which standardization mode firms select. This is the objective of the paper.

\section{Modules and Architectures in ICT Industries}

The main contingency that we argue affects the choice of standardization mode is the nature of the systems technology that the standard pertains to. ICT technologies tend to consist of a system that combines separate modules that enable a complex pattern of interaction. Modules are separate units with a large degree of autonomy. ${ }^{18}$ The degree of modularity is a feature of any kind of system. Schilling ${ }^{19}$ defines it as 'the degree to which a system's components can be separated and recombined ... with little loss of functionality'. She opines that though it is difficult to quantify the degree of modularity, it is possible to rank different systems in terms of their degree of modularity.

Modules need to connect together into a complex, interdependent system, for them to perform useful functions. Complex systems need an architecture, the complex model that defines how a system and its modules interact. ${ }^{20}$ The architecture defines interoperability requirements. Interoperability can be defined as the ability of modules to inter-connect in a way that enhances performance in a predictable manner. By creating interoperability between different modules, new functions and services are made possible. ${ }^{21}$ Compatibility standards guarantee a level of interoperability between modules. They do so by laying down specifications that, if followed, enable interoperability.

Architectures and modules are loosely coupled if the architecture is flexible as to which new modules can be integrated and the modules can be integrated in different architectures. The Windows PC architecture has, for instance, integrated numerous modules in its basic design (e.g. various types of modems), while some modules are integrated in various architectures, such as the USB bus in Windows PCs, Apple Macintosh computers and digital cameras. The flexibility of modular systems enables both the rapid adoption of new technologies and the retention of old technologies or components in a new architecture. ${ }^{22}$ Internet telephony is an example where a modular architecture enables new combinations between components, pertaining to voice, video and data communication. These new combinations in turn facilitate service innovations. ${ }^{23}$ As a result of this flexibility, modularity tends to reduce switching costs between technologies, at least at the level of individual components. ${ }^{24}$ Whenever firms make an investment in a technology, they create the liability of switching costs: if they want to switch to another technology later, they incur switching costs of retooling, retraining and other costs that they would not have incurred, had they continued with their 
prior technology. Modularity reduces switching costs among others by retaining components of established technologies, while integrating new elements. These switching costs have an effect on standardization processes.

\section{Technological Constraints on Organization}

Having discussed the degree of modularity and the associated switching costs, we need to see whether this is a contingency that affects how a standardization process is organized. The literature on modular systems recognizes the interaction between modularity (of technology, systems, and products) and organization (of firms, networks, or markets). Modular systems enable division of labour between suppliers and innovators. They tend to call for networks of suppliers and users. ${ }^{25}$ In case studies of the high-fidelity and stereo systems and personal computer industries, Langlois and Robertson ${ }^{26}$ show that if the products are modular, customers can mix and match components from various suppliers to create the product variety that suits them best. The need to assemble separate components does create assembly costs and transaction (information search) costs. Modularity may raise the fixed costs of developing the system. ${ }^{27}$

It seems intuitive that a modular system will be associated with a decentralized, network-like, industry structure. Specialist firms may supply modules. Generalist firms combine these modules to supply products or services. The relationship between modularity and industry structure may be more complicated, however. ${ }^{28}$ Within a decentralized network-like organizational structure authority and entrepreneurship are required to coordinate innovations. This limits the modularity of the organization structure. ${ }^{29}$ We can learn from this that even when modules can be easily integrated in a decomposable technical system, decision making in the associated industry still needs to be coordinated, which can be costly and time consuming.

We can extend this argument to the organization of the standard setting process. Since the 1990s, two aspects of standardization processes in the ICT industries stand out. One aspect is that technologies in the ICT industries are perceived to have widely different degrees of modularity. Internet technologies, for instance, are usually considered highly modular. The other aspect is the evolution of a menu of standardization modes that allows firms to choose their preferred mode. In the ICT industries there are many cases of the same firms choosing very different standardization modes for different technologies. Their choices range from market selection of standards, such as in streaming video standards, competing groups of standards or architectures, as with the choice between the SIP and H.323 architectures for Internet telephony, and the case of negotiated development of the XML markup language in the World Wide Web consortium.

The point in this article is that these two aspects are interrelated. Where architectures become more modular, switching costs decrease. The switching costs in turn affect the preference for the different standardization modes. Which mode firms choose will also depend, however, on other conditions, notably, the extent of positive network externalities that can be realized and the competitive game play between the firms. 
The pioneering paper to link the nature of a technology to the standardization mode is by $\mathrm{Choi}^{30}$ who explores the link between timing, switching costs and standardization mode in a paper on experimentation and learning. If firms do not standardize initially, they can experiment with different technologies. Once they discover which of these works best, the firm that adopted the (ex post) inferior technology switches to the ex post superior technology. This leads to de facto standardization. If, however, the firm that experimented with the (ex post) inferior technology has high switching costs, it may not switch. A standard does not emerge, therefore, and an inferior technology is utilized. Again, as in Farrell and Saloner, ${ }^{31}$ the market may fail to establish a de facto standard. Choi ${ }^{32}$ succeeds in explaining why. The switching costs make it too costly for firms to switch to a standard, even when there is consensus about which technology should be the industry standard. If the firms choose a standard ex ante, for example in a negotiation process, they would not incur switching costs, and would certainly realize the positive network externalities of adopting a standard. They may, however, choose the ex post inferior standard. According to Choi's approach, the choice of standard selection mode is a choice between the value of experimentation (an advantage of market selection) and positive network externalities (an advantage of central coordination).

The papers by Farrell and Saloner ${ }^{33}$ and $\mathrm{Choi}^{34}$ explain when the market selection mode fails to converge on a de facto standard. Firms take uncoordinated decisions ex ante and they may be unable to renege on them ex post because of the switching costs. This suggests how companies can achieve a beneficial hybrid standardization mode. Let firms adopt different technologies ex ante, select a consensus standard subsequently, and allow them to switch to the consensus standard ex post by using modular system technologies with low switching costs. Where we need to modify Choi's ${ }^{35}$ approach is that the process of choosing a technology to standardize on takes time. This presents vendors with the need to choose between becoming active now and standardize later, or standardize first and become active later. For Choi, this point is less relevant, as he focuses on end users, the potential adopters of given (but initially not entirely understood) technologies. To understand the timing aspect of the standardization mode we need to consider the competitive game play between vendors.

\section{Competitive Game Play between Vendors}

To analyse how economic agents choose to organize a standardization process, we focus on a specific kind of competitive interaction. We study cases where a new technology is applied to a new product that substitutes for an existing product. Both products are services with network features. The Internet and mobile telecommunication have, for example, given rise to innovations that substitute for existing data communication and voice communication services. ${ }^{36}$ A supplier who uses the new technology reduces the revenues of the established supplier of an existing product. The latter may cooperate with the former to develop an industry standard. The industry standard would create compatibility between the various products of the existing and new suppliers. ${ }^{37}$ Their final customers experience a positive network externality by being able to communicate 
with each other, whichever supplier they use. The suppliers can internalise parts of these gains of consumer utility into enhanced profits.

Standardization has an effect on entry. In their study of the semiconductor industry in the 1980s, Kogut et al. ${ }^{38}$ found that the greater the ability of an established firm to set standards, the more likely that it is a desirable partner for entrants. Moreover, the more centralized networks are around incumbent firms, the more entry would occur. Entrants are deterred by uncertainty about which technology will become the standard. The more centralized the network is, the more likely that the central player can set an industry standard, which in turn invites entry. In his study of the Swiss international trade, Blind ${ }^{39}$ found that international standards open domestic markets for foreign importers and tend to reduce Swiss net exports.

When established firms and newcomers compete in a case where standardization benefits exist, the firms face two decisions. First, a new supplier needs to choose the timing of entry. It may enter the market early, using the new technology, or it may wait till an industry standard is developed. Participating in a standard development process tends to be time consuming. Early entry speeds up the revenue stream and may create a competitive early move advantage. If a standard emerges later, it does have to switch to the standardized technology. This calls for switching costs. These costs consist of, for example, adding interfaces, updating hardware and software, and installing gateways. The firm can avoid these switching costs by entering the market later, using the updated, standardized technology. The newcomer therefore faces a trade-off between early revenues and later switching costs. In a time-market evaluation of different investment proposals, the need to standardize can be considered a liability in estimating the time-to-market of a new project. ${ }^{40}$

An established supplier has to choose whether to cooperate with the newcomer to develop an industry standard. If it does, the firms make it possible to realize positive network externalities. Whether positive network externalities for consumers translate into profits for the suppliers depends on how they compete in the product market. If a standard could make the services of both firms better substitutes, the resulting price competition between the vendors might reduce their profits. ${ }^{41}$ Standardizing on compatibility features does leave room for differentiating the products. An important aspect of standardization is, therefore, the extent to which it would reduce product differentiation, increase price competition and reduce profits.

Participating in a standard development process calls for an established vendor to switch to the standardized technology. Doing so, it incurs switching costs. An alternative strategy can be to update its technology, imitating somewhat the new technology of the entrant. The firm is likely to respond to the innovative entry, especially given the commitment and the public nature of it when a rival introduces a proprietary technology. ${ }^{42}$ This strategy leads to a market with competing technologies. The result is that some positive network externalities are not realized. An established supplier therefore faces the trade-off between, on the one hand, positive network externalities and, on the other hand, a costly standard setting process and incurring switching costs.

To analyse how vendor competition affects the standardization mode, we thus 
need to pay attention to the duration of a standardization process, the switching costs, the effect of externalities and standardization on profits and the link between standardization and entry. We next explore a game theoretic analysis to develop an explanatory framework for the selection of standardization mode.

\section{The Model}

We model decision making by firms to explore the basic forces that give rise to these scenarios. There are two firms, the incumbent firm, firm 1, and an entrant, firm 2. The market has two time periods. First, firm 2 (the newcomer) decides whether or not to enter the product market in period 1. This stage determines product market competition (monopoly or duopoly) and pay-offs in period 1 . Then, both firms decide whether or not to cooperate in period 1 to develop a standard for period 2. There is only cooperation in period 1 if both firms agree to that. If they cooperate, they both switch to that standard in period 2. Adopting the standard creates a positive network externality for their final customers. Cooperating is costly for the firms and so is switching to a different technology. Firm 2 can avoid the switching cost by delaying its entry until period 2. Firm 1 can only avoid it by not cooperating for an industry standard in the first place. The penalty for not cooperating is the loss of a positive network externality in period 2.

The interplay of these two decision makers and their trade-offs suggests that in the simplest case, firms face three scenarios with their associated standardization modes:

- Scenario 1 (competing technologies): the newcomer innovates early with a product that substitutes for or competes with the established firm. The established firm reacts subsequently by improving its technology by means of imitation. Customers have to choose between competing technologies, and fail to realize a network externality.

- Scenario 2 (hybrid standardization): the newcomer introduces its innovation early, and soon initiates cooperation with the established firm to develop a standard. Both firms switch to the industry standard once it is there. From that point on, they again compete in the market, but this time they realize a positive network externality for their final customers.

- Scenario 3 (negotiated standardization): the newcomer delays its market introduction and cooperates with the established firm to develop an industry standard. Once the standard is there, the newcomer enters the market and both firms use the standardized technology for their product. The final customers choose between both suppliers. They realize a positive network externality among themselves, independently from the identity of their supplier.

We refer to these scenarios as S1, S2 and S3, respectively. Figure 1 summarizes the sequences of choices and the resulting scenarios.

We use the following terminology for the game:

- Monopoly profit of the incumbent firm 1: $a$.

- Duopoly profits when firms 1 and 2 compete in the product market in period 1 without adopting a standard: $b$. 


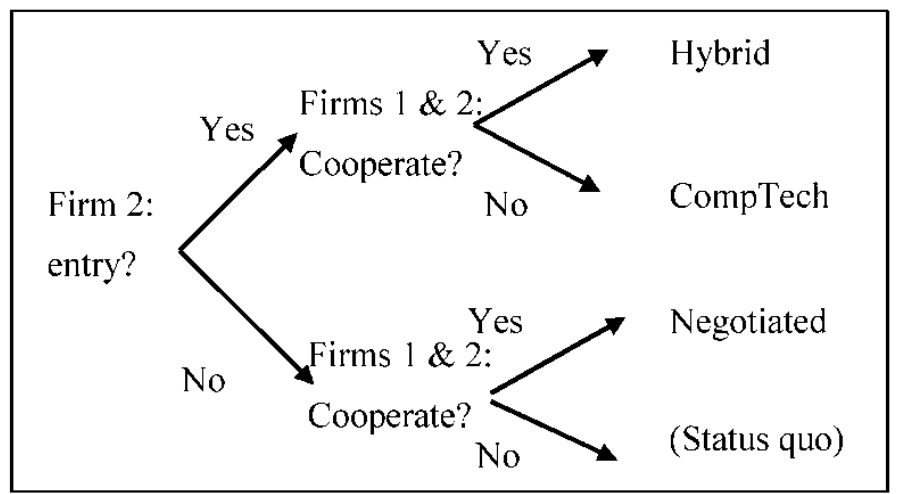

Figure 1. Sequence of moves.

- Duopoly profits when firms 1 and 2 compete in the product market in periods 1 or 2 with compatible standardized technology: $b+c$.

- Switching cost in period 2 for firm 2 from own technology to jointly developed standard: $d_{2}$.

- Switching cost in period 2 for firm 1 from own technology to jointly developed standard: $d_{1}$.

- Payoff of firm 2 in period 2 when no standard was created: $b$.

- Payoff of firm 1 in period 2 when firm 2 entered in period 1 , no standard was created, and firm 1 unilaterally imitates aspects of firm 2's technology: $b+e$.

- Cooperation costs per firm in period $1: f$.

- Discount factor of period 2 towards period 1: $\delta$.

These parameters allow us to explore the effect of how much the positive externalities increase profits $(c)$, how costly it is for either firm to switch to the standard $\left(d_{1}\right.$, resp. $\left.d_{2}\right)$, how intense product market competition is $(b)$, how much firm 1 can increase its profits by unilaterally imitating the entrant's technology $(e)$, how costly the negotiation process is $(f)$ in terms of man power and other expenses, and finally, how high firms value the revenues of period $2(\delta)$. Table 1 contains the pay-off matrix:

In order to focus on interesting cases, we make the following assumptions:

Assumption 1: Duopoly competition decreases and compatibility increases profits: $2 b<a<2 b+2 c$.

Assumption 2: The gain of compatibility outweighs the switching costs: $d_{1}<c$, $d_{2}<c$.

Assumption 3: If firm 1 imitates firm 2 rather than cooperating with it, its gain in period 2 is relatively small: $0<e<c$. 
Table 1. Pay-off matrix of the two-stage game

\begin{tabular}{|c|c|c|c|c|}
\hline \multirow{5}{*}{\multicolumn{2}{|c|}{ Pay-offs (firm 1, firm 2) }} & \multicolumn{3}{|l|}{ Firm 2} \\
\hline & & \multicolumn{3}{|l|}{ Enter in period 1? (1st stage) } \\
\hline & & Yes & \multicolumn{2}{|l|}{ No } \\
\hline & & $\begin{array}{l}\text { Cooperate with firm } 1 \text { in period } 1 \text { ? } \\
\text { (2nd stage) }\end{array}$ & \multicolumn{2}{|c|}{$\begin{array}{l}\text { Cooperate with firm } 1 \text { in period } \\
1 \text { ? }\end{array}$} \\
\hline & & Yes & Yes & No \\
\hline \multirow{2}{*}{$\begin{array}{l}\text { Firm 1: } \\
\text { cooperate with } \\
\text { firm } 2 \text { in period } \\
1 ?\end{array}$} & Yes & $\begin{array}{l}b-f+\delta\left(b+c-d_{1}\right), \quad b+\delta(b+e), b+\delta b \\
b-f+\delta\left(b+c-d_{2}\right)\end{array}$ & $\begin{array}{l}a-f+\delta\left(b+c-d_{1}\right) \\
-f+\delta(b+c)\end{array}$ & $a+\delta b, \delta b$ \\
\hline & No & $b+\delta(b+e), b+\delta b \quad b+\delta(b+e), b+\delta b$ & $a+\delta b, \delta b$ & $a+\delta b, \delta b$ \\
\hline
\end{tabular}

\section{Solving the Second Stage, the Choice of Cooperating}

There are two kinds of second stage of the game, depending on whether firm 2 decided to enter in period 1, the first stage of the game. If firm 2 did not enter in period 1, firm 1 cooperates with it if $a-f+\delta\left(b+c-d_{1}\right)>a+\delta b$, that is, if

$$
\delta c>f+\delta d_{1}
$$

Firm 2 cooperates with firm 1 , if $-f+\delta(b+c)>\delta b$, that is, if

$$
\delta c>f
$$

This Nash equilibrium is Pareto efficient, compared to non-cooperation, if $a-f+\delta\left(b+c-d_{1}\right)>a+\delta b$ and $-f+\delta(b+c)>\delta b$. These conditions hold if and only if conditions (1) and (2) hold. Taken together, with $d_{1}>0$, these conditions imply that both firms cooperate to develop an industry standard if and only if condition (1) holds. In that case, scenario 3 applies. If condition (1) does not hold, the firms compete in period 2 (a variant of scenario 1, competing technologies, restricted to the second period).

If firm 2 did enter in period 1 , then firm 1 will also want to cooperate if $b-f+\delta\left(b+c-d_{1}\right)>b+\delta(b+e)$, that is $\delta\left(c-d_{1}\right)>\delta e+f$ or:

$$
\delta(c-e)>f+\delta d_{1}
$$

This implies that the discounted benefit from developing joint compatibility versus unilateral imitation, $\delta(c-e)$, should exceed the coordination and adjustment cost towards the new standard. The condition for firm 2 to accept cooperation is: $b-f+\delta\left(b+c-d_{2}\right)>b+\delta b$, that is:

$$
\delta c>f+\delta d_{2}
$$

Only if both conditions hold, that is, if $\delta c>\max \left\{f+\delta d_{1}+\delta e, f+\delta d_{2}\right\}$, will firms 1 and 2 cooperate in period 1 and switch to the standard in period 2 (scenario 2 , hybrid standardization). The outcome where neither cooperates is always a 
Nash equilibrium (in the subgame where firm 2 entered in period 1). The payoffs for both are in this case: $(b+\delta(b+e), b+\delta b)$. The cooperation equilibrium is Pareto efficient, compared to the non-cooperation Nash equilibrium, if $b-f+\delta\left(b+c-d_{1}\right)>b+\delta(b+e)$ and $b-f+\delta\left(b+c-d_{2}\right)>b+\delta b$. These two conditions are satisfied if and only if: $\delta\left(c-d_{1}\right)>f+\delta e$ and $\delta\left(c-d_{2}\right)>f$. In other words, the cooperation equilibrium is Pareto efficient if and only if conditions (3) and (4) pertain. If firm 2 enters in period 1, both firms will cooperate on a standard in period 1 and adopt it in period 2, if and only if:

$$
\delta c>\max \left\{f+\delta d_{1}+\delta e, f+\delta d_{2}\right\} .
$$

If the condition holds, scenario 2 applies. If condition (5) does not hold and firm 2 enters in period 1, then the two firms compete in period 2 (scenario 1, competing technologies).

Table 2. Results of the second stage (the choice of cooperation mode)

\begin{tabular}{llcl}
\hline $\begin{array}{l}\text { Did firm 2 } \\
\text { enter in period } \\
1 \text { (1st stage)? }\end{array}$ & $\begin{array}{l}\text { Do 1 and 2 cooperate } \\
\text { (2nd stage)? }\end{array}$ & $\begin{array}{r}\text { Outcome } \\
\text { (scenario) }\end{array}$ & Pay-offs (firm 1, firm 2) \\
\hline No & Yes, if $\delta c>f+\delta d_{1}$ & 3 & $\begin{array}{l}a-f+\delta\left(b+c-d_{1}\right), \\
-f+\delta(b+c)\end{array}$ \\
\cline { 2 - 4 } & No, if $\delta c<f+\delta d_{1}$ & 1 & $a+\delta b, \delta b$ \\
\hline Yes & $\begin{array}{l}\text { Yes, if } \delta c>\max \left\{f+\delta d_{1}+\delta e,\right. \\
\left.f+\delta d_{2}\right\}\end{array}$ & 2 & $\begin{array}{l}b-f+\delta\left(b+c-d_{1}\right), \\
b-f+\delta\left(b+c-d_{2}\right)\end{array}$ \\
\cline { 2 - 4 } & $\begin{array}{l}\text { No, if } \delta c<\max \left\{f+\delta d_{1}+\delta e,\right. \\
\left.f+\delta d_{2}\right\}\end{array}$ & 1 & $b+\delta(b+e), b+\delta b$ \\
\hline
\end{tabular}

\section{Solving the First Stage of the Game}

Anticipating the outcome of the second stage of the game (the results in Table 2), firm 2 makes a choice about entry in period 1 , in the first stage of the game. The outcome depends on the parameters. For example, if $\delta c>\max \left\{f+\delta d_{1}+\delta e\right.$, $\left.f+\delta d_{2}\right\}$ and $\delta c>f+\delta d_{1}$, firm 2 compares its pay-offs when it enters in period 1 $\left(b-f+\delta\left(b+c-d_{2}\right)\right)$ to the pay-offs when it does not enter $(-f+\delta(b+c))$. The former exceeds the latter if $b / \delta>d_{2}$. If that condition applies, scenario 2 applies: firm 2 enters the market in period 1 and cooperates with firm 1 to set an industry standard. If either $e>0$ or $d_{2}>d_{1}$, it holds that $\max \left\{f+\delta d_{1}+\delta e\right.$, $\left.f+\delta d_{2}\right\}>f+\delta d_{1}$.

Table 3 combines the results from the first and second stage to link the parameters to the final outcome.

This gives the following outcome, the core result of the model: 
Table 3. Final outcome (scenario) of the game

\begin{tabular}{lccc}
\hline Condition & $\begin{array}{c}\text { Additional } \\
\text { condition }\end{array}$ & $\begin{array}{c}\text { Does firm 2 enter } \\
\text { in period 1? }\end{array}$ & $\begin{array}{c}\text { Outcome } \\
\text { (Scenario) }\end{array}$ \\
\hline$\delta c>\max \left\{f+\delta d_{1}+\delta e, f+\delta d_{2}\right\}>f+\delta d_{1}$ & $b / \delta>d_{2}$ & Yes & 2 \\
& $b / \delta<d_{2}$ & No & 3 \\
$\operatorname{Max}\left\{f+\delta d_{1}+\delta e, f+\delta d_{2}\right\}>\delta c>f+\delta d_{1}$ & $b+f>\delta c$ & Yes & 1 \\
$\operatorname{Max}\left\{f+\delta d_{1}+\delta e, f+\delta d_{2}\right\}>f+\delta d_{1}>\delta c$ & $b+f<\delta c$ & No & 3 \\
\hline
\end{tabular}

Proposition 1: Subgame perfect equilibrium of the game:

\begin{tabular}{l|l} 
Firm 2 enters \\
in period 1
\end{tabular}$\quad \begin{aligned} & \text { Yes }\left[\begin{array}{l}\text { Both cooperate (S2) if } \delta c>\max \left\{f+\delta d_{1}+\delta e, f+\delta d_{2}\right\}>f+\delta d_{1} \text { and } b / \delta>d_{2} \\
\text { No cooperation (S1) if either } \max \left\{f+\delta d_{1}+\delta e, f+\delta d_{2}\right\}>f+\delta d_{1}>\delta c \\
\text { or }\left\{\max \left\{f+\delta d_{1}+\delta e, f+\delta d_{2}\right\}>\delta c>f+\delta d_{1} \text { and } b+f>\delta c\right\}\end{array}\right. \\
& \operatorname{No}\left[\begin{array}{l}\text { Both cooperate (S3) if either }\left\{\delta c>\max \left\{f+\delta d_{1}+\delta e, f+\delta d_{2}\right\}>f+\delta d_{1}\right. \\
\left.\text { and } d_{2}>b / \delta\right\} \text { or }\left\{\max \left\{f+\delta d_{1}+\delta e, f+\delta d_{2}\right\}>\delta c>f+\delta d_{1} \text { and } \delta c>b+f\right\} \\
\text { No cooperation - dominated by scernario } 1\end{array}\right.\end{aligned}$

\section{Results of the Model}

Proposition 1 identifies conditions that are conducive to a hybrid standardization mode (scenario 2):

- the fixed costs of bargaining for standard setting are sufficiently small,

- the switching costs of firm 1 and firm 2 are sufficiently small, and

- the gains to firm 1 for going it alone and imitating firm 2 in period 2 should be sufficiently small.

A modular architecture tends to have low switching costs. By implication, it tends to support hybrid standardization modes.

To create intuition about these results, we consider the special case where bargaining is costless $(f=0)$, but switching costs are real $\left(0<d_{1}\right.$ and $\left.0<d_{2}\right)$. If $f=0$ and given the assumption $2, d_{1}<c$ and $d_{2}<c$, we know that $f+\delta d_{1}<\delta c$ and $f+\delta d_{2}<\delta c$. Figure 2 shows the results.

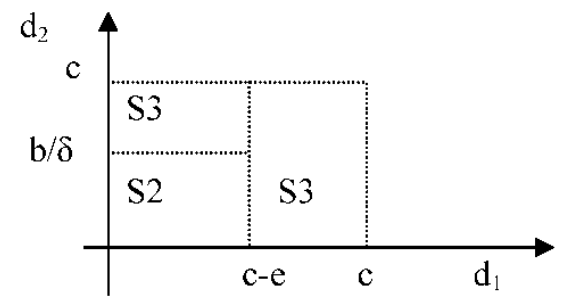

Case $1: \mathrm{b} / \delta<\mathrm{c}$

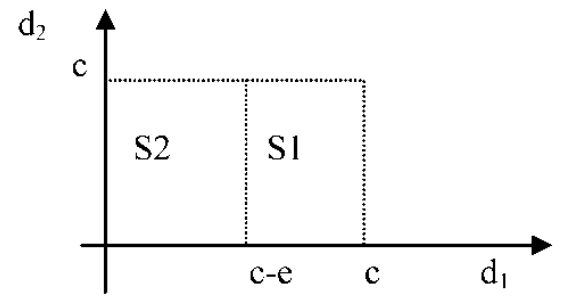

Case $2: \mathrm{c}<\mathrm{b} / \delta$

Figure 2. Two possible outcomes when $f=0$. 
If the established firm has high switching costs, the outcome is either competing technologies (S1) or negotiated standardization (S3). Which of these two outcomes prevails, depends on the relative importance of positive network externalities. If the gain of compatibility $c$ is relatively high (i.e. $c>b / \delta$ ), high switching costs by at least one firm favour scenario 3, negotiated standardization (see Figure 2, case 1). If, on the other hand, the gain of compatibility is relatively low $(c<b / \delta)$, then high switching costs of firm 1 support scenario 1, competing technologies (see case 2 in Figure 2). Firm 1 will not switch from its existing technology to a new one, because of its high switching costs and low gain from compatibility.

Low switching costs $d_{1}$ and $d_{2}$ tend to support scenario 2 (hybrid standardization). Highly modular technologies tend to support hybrid standardization modes, therefore. Highly integrated systems technologies, on the other hand, tend to lead to either market selection of standards or ex ante negotiated standard selection. If we put these results, of proposition 1, Table 3 and Figure 2, in words, what we get is an explanatory framework of the mode of standardization.

\section{Choosing the Degree of Modularity}

In the model above the switching costs have been taken as given. This follows from our approach to explore technology as a contingency factor for the choice of standardization mode. For an innovating firm, however, various aspects of technology are choice variables. This would suggest that the firms can influence the level of switching costs. This choice will have various constraints, however. Individual ICT technologies tend to be part of systems, most of whose characteristics may have been determined in the past. Systemic decisions tend to require the cooperation of firms. The network of firms may be free to choose, but individual firms may be severely limited in their ability to choose technology characteristics. Within these constraints, however, new technologies do present firms with an ability to choose.

The two firms in our model have different interests with respect to switching costs. If the externality profit bonus is relatively high, case 1 applies (see Figure 2). Only scenarios 2 and 3 apply. The entrant would prefer scenario 2 to hold, while the incumbent firm would prefer scenario 1 . The entrant, firm two, would want switching costs to be as low as possible. Low switching costs enable it to enter the market early (in period 1) and switch to the standard in period two to realize the externality bonus (scenario 2). Firm 1, however, would like to raise switching costs to the point that firm 2 abstains from early entry (scenario 3 ). The incumbent firm would not want its switching costs to be less than $c-e$, or those of firm 2 to be less than $b / \delta$. With these high switching costs, it can delay firm 2's entry into the market to period 2, thus protecting its monopoly profit $a$ by one period. Firm 2 plays along with this strategy, because its wants to be able to realize the externality bonus $c$. If this bonus is relatively high, it has to wait with entry till the standard is set. This situation would justify the feeling, expressed occasionally, that established firms may prolong standardization negotiations in order to protect current revenue flows. ${ }^{43}$ 
If the externality profit bonus is relatively small, case 2 applies (see Figure 2). We argue that in this case the interests of both firms can be aligned. Firm 2 will enter the market early any way (only scenarios 1 and 2 apply). Switching costs only affect what will happen in period 2 . The entrant would benefit from having switching costs as low as possible. If the entrant's switching costs are high, it will not switch to the standard in period 2, and the positive externality bonus is not realized. Firm 1 will consent to reducing switching costs, if the profit of having a standard $\left(=b-f+\delta\left(b+c-d_{1}\right)\right.$, see Table 2$)$, exceed the profits of progressing unilaterally $(=b+\delta(b+e))$. With the assumption that case 2 applies $(c<b / \delta)$, this condition means that $e+d_{1}<c<b / \delta$ and $f<\delta\left(c-e-d_{1}\right)$. Firm 1 will thus accept a lower level of switching costs, if the costs of negotiating a standard $f$ are low, the externality profit bonus $c$ is sufficiently high, yet low enough for case 2 to apply $(c<b / \delta)$, and the profit enhancement from unilaterally imitating elements of firm 2's technology into its own service $e$ is sufficiently low.

These results give the following outcome:

Proposition 2: The two firms will only consent to standardize on a highly modular technology system, leading to a hybrid standardization mode, if the following conditions hold:

- The payoff $e$ when firm 1 unilaterally imitates elements of firm 2's technology into its own service is sufficiently low $\left(e+d_{1}<c<b / \delta\right)$.

- The externality profit bonus $c$ is sufficiently high, yet low enough that the entrant firm 2 will not postpone entry in order to realize the positive externality $\left(e+d_{1}<c<b / \delta\right)$.

- The costs of negotiating a standard $f$ are low $\left(f<\delta\left(c-\mathrm{e}-d_{1}\right)\right)$.

- The discount rate $\delta$ is relatively high.

\section{Interpretation of these Results}

The propositions indicate conditions that have an effect on the standardization mode. Together these conditions form an explanatory framework for the mode of standardization in a systems technology.

- Network externalities: The higher the potential is for positive network externalities (parameter $c$ ) created by new communication services for final customers, the more likely that the standardization process is either a hybrid or a negotiated process. If a standard would make the services of both firms better substitutes, the resulting price competition between the vendors might reduces their profits. The bonus $c$ would be small or negative, and only the scenario of competing technologies would apply.

- Intensity of competition: The more intense the product market competition is between the new and existing firms, the lower the duopoly profit $b$ will be. That would make an outcome of competing technologies (scenario 1) less likely. Firms would cooperate to set a standard for period 2 (scenario 3), and, if switching costs are low, they would compete in period 1 (scenario 2).

- Imitation: If the established firm, firm 1, can imitate its new rival, firm 2, and if that strongly increases its profits in the future (the parameter e), then firm 
1 is less likely to standardize. The larger it is, the more it can achieve network externalities by itself, without any cooperation with firm 2 .

- Switching costs: If the new firm is more flexible than the existing one $\left(d_{2}\right.$ low and $d_{1}$ high), the existing firm's high switching cost makes hybrid standardization less likely. The outcome would be a pure approach of either competing technologies (if the gain of compatibility is fairly small) or negotiated standardization (if the compatibility gain is high).

- Bargaining costs: If bargaining costs $f$ are sufficiently high, scenario 1 prevails, with competing technologies. Conditions that reduce bargaining costs are routines of collaboration, institutions and the incidence of prior contacts between the firms involved that create trust among them. ${ }^{44}$ These conditions would reduce the bargaining costs and make a negotiated or hybrid standardization mode more likely. If the bargaining process could be speeded up, this would mean in our model that period 2 starts earlier. That is, the discount factor $\delta$ increases, the factor $\mathrm{b} / \delta$ decreases and it becomes more likely that case 1 arises rather than case 2 (see Figure 2), and in case 1 scenario 3 becomes more likely than scenario 2 . The hybrid scenario becomes less likely when negotiations lead to a standard more quickly. The entrant is more likely to wait to set a standard first and enter later (scenario 3) when the standard setting period is rather brief.

\section{Cases}

At this point, we may ask whether these three scenarios have examples in reality and moreover, do these cases appear to be consistent with our explanation suggested above? Some well-known examples do indeed seem to be consistent with our description. Table 4 summarizes these cases. While they do not prove the model, they do suggest that the model is on to something.

The long and winding road to high-definition television in Japan, Europe and the USA shows high switching costs and high potential gains (network externalities) in combination with centralized, negotiated selection (if not development and adoption) of a standard. ${ }^{45}$ This outcome is consistent with the situation in case 1 (relatively high externality profit bonus), with high switching costs, where a negotiated standardization mode is predicted.

Using the modular Internet architecture leads to innovatory services, such as Internet telephony, that have lower switching costs than more highly integrated technologies such as traditional circuit-switched telephony. ${ }^{46}$ These Internet services tend to have relatively high indirect externalities: they need large networks of users to achieve economies of scale and to attract revenues, such as advertising revenues. Moreover, users experience direct network benefits by being able to communicate with each other, even if they participate in different networks. Moreover, the revenues on Internet telephony are either zero or small and thus relatively small compared to the direct network externalities. The condition of low switching costs coupled with the direct network externalities of telecommunication services suggest that case 1 applies, with a prediction that hybrid standardization prevails (see Figure 2). This appears consistent with the standardization process of Internet telephony. There is a lot of formal development going on of 
Table 4. Examples of the three standardization scenarios

\begin{tabular}{|c|c|c|c|}
\hline & \multicolumn{3}{|c|}{ Case } \\
\hline & $\begin{array}{l}\text { Personal computer } \\
\text { office software }\end{array}$ & Internet telephony & $\begin{array}{l}\text { High-Definition } \\
\text { Television (by 1992) }\end{array}$ \\
\hline $\begin{array}{l}\text { Technologies, } \\
\text { standards }\end{array}$ & $\begin{array}{l}\text { File formats (Lotus, } \\
\text { dBase file formats) }\end{array}$ & $\begin{array}{l}\text { H.323 } \\
\text { SIP (Session Initiation } \\
\text { Protocol) }\end{array}$ & HDTV \\
\hline Network externality & $\begin{array}{l}\text { Direct: file exchange } \\
\text { between people } \\
\text { Indirect: file exchange } \\
\text { between } \\
\text { complementary } \\
\text { software programs }\end{array}$ & $\begin{array}{l}\text { Direct externality: } \\
\text { communication }\end{array}$ & $\begin{array}{l}\text { High, indirect } \\
\text { (economies of scale in } \\
\text { content production) }\end{array}$ \\
\hline $\begin{array}{l}\text { Switching costs, } \\
\text { modules }\end{array}$ & $\begin{array}{l}\text { Designing file } \\
\text { compatibility into a } \\
\text { program is costly. } \\
\text { For a user to switch } \\
\text { tends to require new } \\
\text { complementary } \\
\text { programs }\end{array}$ & $\begin{array}{l}\text { Modular architecture, } \\
\text { incl. a layered } \\
\text { network architecture }\end{array}$ & $\begin{array}{l}\text { High, coordinated use } \\
\text { of new studio } \\
\text { equipment, } \\
\text { transmission systems, } \\
\text { receivers }\end{array}$ \\
\hline $\begin{array}{l}\text { Standardization } \\
\text { bodies }\end{array}$ & None & $\begin{array}{l}\text { ITU } \\
\text { IETF }\end{array}$ & FCC (in the U.S.) \\
\hline $\begin{array}{l}\text { Standard setting } \\
\text { process }\end{array}$ & $\begin{array}{l}\text { Competing } \\
\text { technologies }\end{array}$ & Hybrid process & Negotiated process \\
\hline Source & $\begin{array}{l}\text { Gandal }^{49} ; \text { Lange }^{55} \\
\text { Shurmer \& Swann }\end{array}$ & $\begin{array}{l}\text { Vercoulen \& van } \\
\text { Wegberg } 46\end{array}$ & Farrell \& Shapiro ${ }^{45}$ \\
\hline
\end{tabular}

platform architectures, such as the H.323 architecture for Internet telephony by the ITU. There are, moreover, collaborative activities in forums and consortia. ${ }^{47}$ These consist of joint efforts to develop technologies for the formal process, and improve inter-operability of services. While negotiations have been taking place, the provision of actual Internet services has expanded too, since the first such service operated by Vocaltec in $1996 .{ }^{48}$

File formats of software programs in the market for PC office software developed into de facto standards. In the late 1980s and early 1990s, the Lotus file format developed into a de facto standard for spreadsheets and database programs. ${ }^{49}$ Gandal $^{50}$ shows that users valued the direct and indirect network externality that results from using software (spreadsheets and database management programs) that was file compatible with the Lotus 1-2-3 spreadsheet format. ${ }^{51}$ In a simulation, calibrated to real market data, Shurmer and Swann ${ }^{52}$ show that several market features including network externalities, which were especially large for Lotus, can best explain the diffusion of the Lotus spreadsheet and its dominance over the alternatives Supercalc and Framework. In the market for database management programs, direct network externalities appear not be large. ${ }^{53}$

In both studies, ${ }^{54}$ complementary products that support a particular de facto 
standard create indirect network externalities. A recent empirical study also supports the view that the extent to which users adopt complementary products tends to drive diffusion of software programs (e.g. computer operating systems) ${ }^{55}$ These complementary products also create switching costs. It is costly for software developers to integrate compatibility with a particular file format into their product, as Gandal assumes, ${ }^{56}$ and users need to buy new complementary goods, should they switch to a product with an incompatible file format. If profit margins are relatively high (high $b / \delta$ ), if rivals can copy newcomer's best features (high $e$ ), and switching costs are high, then case 2 in Figure 2 suggests that scenario 1 applies with competing technologies. This may account for the lack of negotiated work on format standards for office software, even though, from a users' perspective, network externalities are high.

These cases show that the standardization modes identified in the paper exist. They show that they tend to arise in situations similar to the ones identified by our propositions.

There are of course many examples that do not fit quite nicely into the three scenarios in Table 4. One scenario may, for example, give way to another one. If a negotiated standard fails to deliver, the industry consensus behind it may disintegrate. Alternatives may come to be developed, and the situation may slip into one with competing technologies. There is, for example, some dissatisfaction in Europe with WAP (Wireless Application Protocol) technology. Service providers in Europe such as KPN of the Netherlands switched to NTT DoCoMo's Japanese i-Mode technology as an alternative.

Another intermediate case is when firms that appear to lose out in a situation of competing technologies may band together in an effort to set an industry standard. The result may be a switch to a hybrid or negotiated standard setting. For example, there are various providers of incompatible instant messaging services. The uncontested market leader is America Online (AOL), with its own proprietary instant messaging network and technology. At about 131 million registered members, it as a market share of $80 \% .{ }^{57}$ Several providers of instant messaging services have joined together in a consortium to develop a standard, the IMPP, Instant Messaging and Presence Protocol. AOL seems not to participate actively, but has pledged to adopt the standard once it is there.

\section{Conclusion}

The general point of the paper is to show the strong link between two features that many network services have: modular technologies with low switching costs and hybrid standardization processes. More generally, the degree of modularity of a system's technology is a contingency factor for the choice of the mode of standardization. The model is abstracted to demonstrate this point. Just a few conditions of standards (their effects on switching costs, externalities and bargaining costs) suffice to explain in one simple setting many basic characteristics of standardization processes.

The wider story that comes out of this discussion is this. In the ICT industries, vendors are well aware of the strategic potential of standards. They invest resources, people and money, in developing and adopting standards. They 
participate in standardization bodies. One way to get a preferred standard adopted is to influence the process that leads to a standard. In the liberalized ICT industries, there are many different opportunities for firms to choose how and with whom to set a standard. A hybrid standardization process appears an appealing route when it combines the advantages of market selection and negotiated standardization modes. That was indeed the original insight in the seminal paper by Farrell and Saloner. ${ }^{58}$ The hybrid process may also, however, combine the disadvantages of the market selection and negotiated standardization modes. It is only in certain conditions that the hybrid mode indeed appears the preferred route for firms. In choosing a standardization mode, firms balance between imperatives of the competitive environment and constraints from the systems technology that the standard refers to. Our main finding is that the higher the switching costs between technologies are for the vendors, the less willing they are to engage in a hybrid mode.

This analysis helps understand one advantage that the Internet offers to innovations with network characteristics. The Internet has stimulated open standards and modular systems technologies, with low switching costs. One advantage of this approach is that it facilitates hybrid standardization modes. It makes it possible for firms to combine the advantages of market selection of standards (timely market introduction and choice between alternative technologies) with negotiated standardization (to achieve positive network externalities). The era is over where negotiated standardization processes lasted for many years and were unresponsive to business needs and where negotiated processes take time, they have to be justified. ${ }^{59}$ Vendors and potential users do not need to accept it if the market fails to provide them with a de facto standard. The possibilities for cooperation have increased and cooperation need not stand in the way of early market introduction of new products.

In the context of case studies, it will be difficult to measure directly the costs and revenues that drive the standardization mode, notably the switching costs, bargaining costs and positive externalities. However, one can elicit opinions about whether these conditions increased or decreased over a time period. The propositions above can be interpreted dynamically: an increase of the switching costs and other conditions tends to make a particular outcome (a hybrid standardization mode) more likely. The model can therefore predict changes of the standardization mode within the function of changes in perceived levels of switching cost, bargaining costs and externalities.

Future work can go in two directions. First, it may be possible to develop more detailed models, with more powerful (less intuitive) ideas. There are many individual examples where the preferred standardization mode appears to evolve over time. Firms may change their preferences for how to get to a standard. More expanded models might be able to generate these results. It may also be a worthwhile route to open up some black box in the model. These include aspects of standards and the compatibility choice, which have already been discussed elsewhere, albeit not in the present context. These include aspects of technology (by identifying modular components), the bargaining process, networking between firms that jointly control a systems technology, the entry process (e.g. continuous time), the research process (uncertainty, experimentation, externalit- 
ies), intellectual property rights on technologies, competitive pre-emptive moves, consumer utility when consumers experience positive network externalities, and the institutional and regulatory context. Integrating these literatures in the model could be meaningful subsequent steps. Second, game theoretic analyses benefit from more intensive interaction with case studies on how standards actually got selected. Explicitly incorporating each other's approach can be a stepping-stone towards more fruitful exchange of views.

\section{Acknowledgement}

I thank my colleague Martin Carree for his comments, as well as participants in the 2001 EURAS Conference in Delft, The Netherlands, and the SIIT 2001 Conference in Boulder, CO, USA.

\section{Notes and References}

1. G. Tassey, Standardization in technology-based markets, Research Policy, 29, 2000, pp. 587-602, see p. 588.

2. M. L. Katz \& C. Shapiro, Network externalities, competition, and compatibility, American Economic Review, 75 (3), 1985, pp. $424-440$.

3. S. M. Besen \& J. Farrell, Choosing how to compete: strategies and tactics in standardization, Journal of Economic Perspectives, 8 (2), 1994, pp. 117-131.

4. P.Heywood, M. Jander, E. Roberts \& S. Saunders, Standards, the inside story: do vendors have too much influence on the way industry specs are written and ratified? Data Communications, 1997, pp. $59-72$.

5. Ibid.

6. J. L. Funk \& D. T. Methe, Market- and committee-based mechanisms in the creation and diffusion of global industry standards: the case of mobile communication, Research Policy, 30, 2001, pp. 589610; P. Genschel, How fragmentation can improve co-ordination: setting standards in international telecommunications, Organization Studies, 18 (4), 1997, pp. 603-622.

7. P. A. David \& M. Shurmer, Formal standards-setting for global telecommunications and information services: towards an institutional regime transformation? Telecommunications Policy, 20 (10), 1996, pp. 789-815.

8. Ibid.; R. Hempel \& D. W. Walker, The emergence of the MPI message passing standard for parallel computing, Computer Standards \& Interfaces, 21, 1999, pp. 51-62; V. Mangematin \& M. Callon, Technological competition, strategies of the firms and the choice of the first users: the case of road guidance technologies, Research Policy, 24 (3), 1995, pp. 441-458.

9. S. K. Schmidt \& R. Werle, Coordinating Technology: Studies in the International Standardization of Telecommunications (Cambridge, MA, The MIT Press, 1998).

10. Besen \& Farrell, op. cit., Ref. 3; Funk \& Methe, op. cit., Ref. 6.

11. K. Asatani, IP and telecommunication integration: de jure and de facto standards have entered a new era, IEEE Communications Magazine, 1999, pp. 140-147.

12. R. Garud \& A. Kumaraswamy, Changing competitive dynamics in network industries: an exploration of Sun Microsystems' open systems strategy, Strategic Management Journal, 14, 1993, pp. 351-369.

13. S. M. Besen \& G. Saloner, The economics of telecommunications standards, in: R. W. Crandall \& K. Flamm (Eds) Changing the Rules: Technological change, international competition, and regulation in communications (Washington, D.C., The Brookings Institution, 1989), pp. 177-220; Genschel, op. cit., Ref. 6.

14. J. Farrell \& G. Saloner, Coordination through committees and markets, RAND Journal of Economics, 19 (2), 1988, pp. 235-252.

15. Ibid.

16. Ibid.

17. Ibid. 
18. R. Garud \& A. Kumaraswamy, Technological and organizational designs for realizing economies of substitution, Strategic Management Journal, 16, 1995, pp. 93-109; R. M. Henderson \& K. B. Clark, Architectural innovation: the reconfiguration of existing product technologies and the failure of established firms, Administrative Science Quarterly, 35, 1990, pp. 9-30; R. N. Langlois \& P. L. Robertson, Networks and innovation in a modular system: lessons from the microcomputer and stereo component industries, Research Policy, 21, 1992, pp. 297-313; M. A. Schilling, Toward a general modular systems theory and its application to interfirm product modularity, Academy of Management Review, 25 (2), 2000, pp. 312-334.

19. Schilling, op. cit., Ref. 18, p. 315.

20. Henderson \& Clark, op. cit., Ref. 18; C. R. Morris \& C. H. Ferguson, How architecture wins technology wars, Harvard Business Review, 1993, pp. 86-96.

21. P. A. David \& W. E. Steinmueller, Standards, trade and competition in the emerging global information infrastructure environment, Telecommunications Policy, 20 (10), 1996, pp. 817-830.

22. Garud \& Kumaraswamy, op. cit., Ref. 18.

23. C. A. Polyzois, K. H. Purdy, P.-F. Yang, D. Shrader, H. Sinnreich, F. Menard \& H. Schulzrinne, From POTS to PANS: a commentary on the evolution to internet telephony, IEEE Network, 1999, pp. 58-63.

24. C. Y. Baldwin \& K. B. Clark, Managing in an age of modularity, Harvard Business Review, 75 (5), 1997, pp. 84-93; C. R. Morris \& C. H. Ferguson, How architecture wins technology wars, Harvard Business Review, 1993, pp. 86-96.

25. Baldwin \& Clark, op. cit., Ref. 24; Garud \& Kumaraswamy, op. cit., Ref. 18; Langlois \& Robertson, op. cit., Ref. 18.

26. Langlois \& Robertson, ibid.

27. R. N. Langlois, Modularity in technology and organization, Journal of Economic Behavior \& Organization, 49, 2002, pp. 19-37.

28. Ibid.; M. A. Schilling \& H. K. Steensma, The use of modular organizational forms, Academy of Management Journal, 44 (6), 2001, pp. 1149-1168.

29. Langlois, op. cit., Ref. 27.

30. J. P. Choi, Standardization and experimentation: ex ante vs. ex post standardization. European Journal of Political Economy, 12, 1996, pp. 273-290.

31. Farrell \& Saloner, op. cit., Ref. 14.

32. Choi, op. cit., Ref. 30.

33. Farrell \& Saloner, op. cit., Ref. 14.

34. Choi, op. cit., Ref. 30.

35. Ibid.

36. Polyzois et al., op. cit., Ref. 23.

37. Asatani, op. cit., Ref. 11.

38. B. Kogut, G. Walker \& D.-J. Kim, Cooperation and entry induction as an extension of technological rivalry, Research Policy, 24, 1995, pp.77-95.

39. K. Blind, The impacts of innovations and standards on trade of measurement and testing products: empirical results of Switzerland's bilateral trade flows with Germany, France and the UK, Information Economics and Policy, 13 (4), 2001, pp. 439-460.

40. A. Messica \& A. Mehrez, Time-to-market, window of opportunity, and salvageability of a new product development, Managerial and Decision Economics, 23, 2002, pp. 371-378.

41. Besen \& Farrell, op. cit., Ref. 3; M. L. Katz \& C. Shapiro, Product introduction with network externalities, The Journal of Industrial Economics, 40 (1), 1992, pp. 55-83.

42. M.-J. Chen, S. Venkataraman, S. Sloan Black \& I. C. MacMillan, The role of irreversibilities in competitive interaction: behavioral considerations from organization theory, Managerial and Decision Economics, 23, 2002, pp. 187-207.

43. O. Lint \& E. Pennings, The recently chosen digital video standard: playing the game within the game. Technovation, 23 (4), 2003, pp. 297-306.

44. For example, R. Gulati, does familiarity breed trust? The implications of repeated ties for contractual choice in alliances. Academy of Management Journal, 38 (1), 1995, pp. 85-112.

45. Farrell, J. \& Shapiro, C. (1992). Standard Setting in High-Definition Television. Brookings Papers on Economic Activity: Microeconomics, 1992, pp. 1-93.

46. F. Vercoulen \& M. van Wegberg, Standard selection modes in dynamic, complex industries: creating 
hybrids between market selection and negotiated selection of standards (nib98006), University of Maastricht, NIBOR, Maastricht, 1998.

47. Asatani, op. cit., Ref. 11.

48. Vercoulen \& van Wegberg, op. cit., Ref. 46.

49. N. Gandal, Competing compatibility standards and network externalities in the PC software market, Review of Economics and Statistics, 77 (4), 1995, pp. 599-608; M. Shurmer \& P. Swann, An analysis of the process generating de facto standards in the PC spreadsheet software market, Journal of Evolutionary Economics, 5, 1995, pp. 119-132.

50. Gandal, ibid.

51. His evidence is indirect, by showing the price premiums of software programs that are compatible with the Lotus file format.

52. Shurmer \& Swann, op. cit., Ref. 49.

53. Gandal, op. cit., Ref. 49.

54. Gandal, op. cit., Ref. 49; Shurmer \& Swann, op. cit., Ref. 49.

55. R. Lange, S. McDade \& T. A. Oliva, Technological choice and network externalities: a catastrophe model analysis of firm software adoption for competing operating systems. Structural Change and Economic Dynamics, 12, 2001, pp. 29-57.

56. Gandal, op. cit., Ref. 49.

57. Source: C:Net (http://www.cnet.com), 'Group to weigh instant messaging standard proposals', 4 August 2000, and 'FTC unlikely to use messaging against AOL Time Warner', 21 August 2000.

58. Farrell \& Saloner, op. cit., Ref. 14.

59. M. H. Sherif, When is standardization slow? Journal of IT Standards \& Standardization Research, 1 (1), 2003, pp. 19-32. 